\title{
FAKTOR-FAKTOR YANG BERHUBUNGAN DENGAN TINGKAT MOTIVASI PETANI SAWIT DALAM PENGEMBALIAN KREDIT DI KOPERASI BAITUL MAAL WATAMWIL DESA SRIKATON KECAMATAN PONDOK KELAPA KABUPATEN BENGKULU TENGAH
}

\author{
(FACTORS RELATED TO MOTIVATION OF PALM OIL FARMERS TO \\ PAY BACK THEIR LOAN IN BAITUL MAAL WATAMWIL \\ COOPERATIVE SRIKATON VILLAGE PONDOK KELAPA \\ SUBDISTRICT CENTRAL BENGKULU DISTRICT
}

\author{
Hendarto, Redy Badrudin, M. Zulkarnain Yuliarso \\ Jurusan Sosial Ekonomi Pertanian Fakultas pertanian Universitas Bengkulu
}

\begin{abstract}
The objectives of this research were to find out the level farmer's motivation in the refunding their loan at Baitul Maal Watamil (BMT) and to determine factors are associated with the level of motivation. This research was held on 15 November 2011 to 15 Desember 2011 in Srikaton Village in Central Bengkulu Regency. The respondents of this research were taken by using census technique. The results of this research indicate that the level of motivations to repay the loans at Baitul Maal Watamil (BMT) could be categorized in medium level or quite good. Then the factors related to the level of farmers motivations in refunding the credit, there were three factors namely. First the level of farming experience. Second the value of collateral and the last level of farmers perceptions of BMT cooperative and the credit program of cooperative it self
\end{abstract}

Keywords: motivation, farmer, member of BMT, loan repayment

\section{PENDAHULUAN}

Pembangunan koperasi sebagai bagian integral dari pembangunan ekonomi perlu dilanjutkan dan diarahkan untuk mewujudkan koperasi sebagai badan usaha dan sekaligus sebagai gerakan ekonomi rakyat serta sebagai sokoguru perekonomian nasional.Pembangunan koperasi merupakan wadah untuk menggalang kemampuan ekonomi rakyat disemua kegiatan perekonomian, sehingga mampu berperan utama dalam peningkatan kondisi ekonomi dan kesejahteraan masyarakat. 
Pada hakekatnya koperasi berorientasi tidak semata-mata mencari keuntungan (non-profit) akan tetapi lebih mengutamakan kesejahteraan anggota, dan dari sekian hasil usaha yang didapatkan oleh koperasi yang sisa usahanya akan dibagikan kepada anggotanya, sesuai dengan besar kecilnya jasa anggota dalam usaha koperasi tersebut. Untuk itu koperasi perlu terus dibina dan dikembangkan agar tumbuh sehat dan kuat sehingga koperasi akan semakin berakar dan perannya semakin besar dalam kehidupan sosial ekonomi masyarakat di pedesaan.

Peranan pemerintah sangat besar dalam upaya mewujudkan kemandirian koperasi. Keterlibtan pemerintah dalam pembinaan koperasi secara normative ditunjukkan dalam pasal 33 UUD 1945 dan Bab XII pasal 60 sampai 64 UU No. 25/1992 tentang perkoperasian.Keterlibatan pemerintah dimaksudkan untuk mempercepat terwujudnya demokrasi ekonomi.Untuk memperkuat posisi koperasi, perlu dikembangkan konsep-konsep keterkaitan antara koperasi dengan sektor swasta dan Badan Usaha Milik Negara (BUMN) atas dasar hubungan yang rasional dan wajar yaitu adanya upaya saling membantu dan saling membutuhkan. Dimana pada dasarnya bentuk kerjasama semacam ini terwujud dari peran aktif tak langsung masyarakat dalam pembangunan ekonomi nasional.

Kredit merupakan salah satu aset yang sangat penting dalam menunjang kegiatan perbankan, maka dalam suatu proses pemberian kredit diperlukan suatu mekanisme atau tatacara yang diatur sedemikian rupa. Hal ini dimaksudkan agar kredit yang diberikan tidak bermasalah karena kredit juga merupakan bentuk kepercayaan pihakkoperasi kepada pihak peminjam yang menggunakanya. Semua ini tidak terlepas dari hal-hal yang yang mungkin terjadi baik penyelewengan, penyimpangan bahkan kemacetan kredit sehingga akan menpertinggi resiko kredit.

Koperasi Baitul Maal Wat Tamiil (BMT) Desa SrikatonKecamatan Pondok Kelapa Kabupaten Bengkulu Utara merupakan koperasi yang bergerak pada usaha simpan pinjam (Kredit) dengan Bank BRI sebagai Bank pendamping yang menggunakan sistem kemitraan. Memiliki badan hukum Nomor: 008/BH/DKUKM/V/2007. Nasabah petani sawit secara khusus merasakan dampak kredit yang diberikan oleh Koperasi Baitul Maal Wat Tamiil yang bekerjasama dengan pihak bank BRI sebagai mitra dalam hal ini.Karena mereka dapat memperoleh bantuan dengan sistem yang mudah mereka pahami dalam artian pihak koperasi memberikan penjelasan terlebih dahulu sebelum petani menerima pinjaman kredit. Modal merupakan salah satu faktor produksi yang penting pada sektor pertanian di samping faktor-faktor produksi yang lainnya.(tanah, tenaga kerja dan menajemen). Hal ini dikarenakan modal selalu dibutuhkan untuk membiayai seluruh kegiatan usaha tani, agar petani dapat melakukan perbaikan teknologi pertanian maupun metode-metode baru lainnya. Dalam hal ini petani sawit di Kecamatan Pondok Kelapa Kabupaten Bengkulu tengah membutuhkan modal dalam membantu keadaan mereka disaat memerlukan dana untuk pemenuhan sarana usaha tani sawit 
Berdasarkan latar belakang di atas, maka tujuan dari penelitian ini adalah 1) Untuk mengetahui bagaimana tingkat motivasi petani sawit yang menjadi anggota koperasidalam pengembalian kredit pada koperasiBaitul Maal Wat Tamiil (BMT) di Desa SrikatonKecamatan Pondok Kelapa Kabupaten Bengkulu Tengah. 2) Untuk mengetahui faktor-faktor yang berhubungan dengan tingkat motivasi petani sawit yang menjadi anggota koperasi dalam pengembalian kredit, 3). Untuk mengetahui apakah tingkat motivasi petani sawit yang menjadi anggota koperasi berhubungan nyata dengan tingkat pengembalian kredit.

\section{METODE PENELITIAN}

\section{Metode Penentuan Lokasi}

Penentuan lokasi penelitian ini dilakukan dengan sengaja (Purposive), yaitu pada Koperasi Baitul Maal Wat Tamiil (BMT) Desa Srikaton Kecamatan Pondok Kelapa Kabupaten Bengkulu Tengah.Pemilihan lokasi ini berdasarkan atas pertimbangan bahwa Koperasi Baitul Maal Wat Tamiil (BMT) Desa Srikaton Kecamatan Pondok Kelapa Kabupaten Bengkulu Tengah, merupakan salah satu penyalur kredit kepada petani sawit Desa Srikaton Kecamatan Pondok Kelapa Kabupaten Bengkulu Tengah.

\section{Metode Pengambilan Responden}

Metode pengambilan responden yang digunakan dalam penelitian ini adalah metode sensus, di mana semua populasi digunakan sebagai sample yaitu pada petani sawit yang mengambil kredit di koperasi BMT (Sugiyono, 1997). Berpedoman pada pendapat di atas, maka jumlah sample dalam penelitian ini adalah semua populasi yaitu 35 orang (informasi terakhir yang didapat).Di mana yang menjadi populasinya adalah petani sawit yang menjadi anggota koperasi BMT.

\section{Metode Pengumpulan Data}

Data yang dikumpulkan dalam penelitian ini adalah meliputi data primer dan data sekunder.Data primer diperoleh melalui observasi dan melalui wawancara langsung dengan responden menggunakan daftar pertanyaan (kuisioner) yang telah dipersiapkan terlebih dahulu.Data sekunder diperoleh dari literatur-literatur atau pustaka dan instansi-instansi atau lembaga-lembaga yang terkait dengan penelitian ini.

\section{Metode Analisa Data}




\section{Analisis Tingkat Pengembalian Kredit}

Untuk melihat tingkat pengembalian kredit menurut Pasaribu (2006) pada petani sawit yang mengambil kredit di koperasi BMT maka digunakan rumus sebagai berikut

$$
\mathrm{Y}=\frac{a}{b} \times 100 \%
$$

dimana Y adalah Tingkat Pengembalian kredit (\%), $a$ adalah angsuran sampai bulan terakhir (Rp), dan badalah Total angsuran sampai bulan terakhir (target) (Rp).

\section{Hubungan Antara Faktor-faktor yang Mempengaruhi Tingkat Motivasi Petani Dalam Pengembalian Kredit.}

Data-data baik mengenai karakteristik petani sebagai responden, persepsi petani dan tingkat motivasi petani dalam pengembalian kredit dianalisis secara deskriptif dengan menggunakan tabel-tabel distribusi frekuensi dan persentase. Analisis kualitatif digunakan untuk lebih mendukung dan memperjelas data kuantitatif yang dipaparkan, sehingga antara data kuantitatif dan kualitatif bersifat saling melengkapi.

Untuk variabel persepsi petani dan tingkat motivasi petani dalam pengembalian kredit diukur dengan menggunakan parameter di mana jenjang kategorinya disesuaikan dengan pertanyaan/pernyataan yang diberikan. Setiap skor yang diperoleh responden dari parameter dijumlahkan, rata-rata skor dari keseluruhan responden dijadikan untuk melihat persepsi petani dan tingkat motivasi dalam pengembalian kredit yang dilakukan secara perhitungan skala interval.

Untuk data rasio (pendidikan formal, luas lahan, jumlah tanggungan keluarga, lamanya berusaha tani, nilai jaminan dan penerimaan usaha tani) menggunakan perhitungan Standar Deviasi yang dirumuskan :

$$
\mathrm{sd}=\sqrt{\frac{1}{n-1} \sum\left(x_{i}-\bar{x}\right)^{2}}
$$

dimana sd adalah Standar deviasi, $x_{i}$ adalah Jumlah skor pada responden $i, \bar{x} \quad$ adalah Rata-rata skor, dan $\mathrm{n}$ adalah Jumlah responden

Dengan jenjang kategori faktor-faktor yang diteliti meliputi tinggi, sedang dan rendah, yaitu (a) $x_{i}>(\bar{x}+1 / 2 s d)=$ Tinggi, baik, (b) $\left(\bar{x}-\frac{1}{2} s d\right) \leq x_{i} \leq\left(\bar{x}+\frac{1}{2} s d\right)=$ Sedang, biasa, dan (c) $x_{i}<\left(\bar{x}-\frac{1}{2} s d\right)=$ Rendah, jelek

Data-data ordinal menggunakan perhitungan interval klas yang dirumuskan : 


$$
\text { Interval Klas }=\frac{\sum \text { Nilai maksimal }-\sum \text { Nilai minimal }}{\sum \text { Klas }}
$$

dengan kategori: (a) $x>$ Nilai maksimal-Interval Klas $=$ Tinggi, baik, sering, (b) Nilai minimal + Interval Klas $\leq \mathrm{x} \leq$ Nilai maksimal - Interval Klas adalah sedang, kadang-kadang, dan (c) $x<$ Nilai minimal + Interval Klas $=$ Rendah, jelek, tidak pernah. Dimana, Nilai maksimal $=$ Skor tertinggi (3) $x$ jumlah pertanyaan, dan Nilai minimal $=$ Skor terendah (1)x Jumlah pertanyaan.

Untuk menjawab tujuan kedua dan ketiga dari penelitian ini, dalam mengkaji hubungan antara variabel bebas $\left(\mathrm{X}_{\mathrm{i}}\right)$ dengan tingkat motivasi petani sebagai variabel antara $(\mathrm{Y})$ dan hubungan antara variabel tingkat motivasi $(\mathrm{Y})$ dengan tingkat pengembalian kredit $(\mathrm{Z})$ digunakan analisis statistika nonparametrik, yaitu uji korelasi Rank Spearman $\left(r_{s}\right)$. Dalam menghitung koefesien regresi $\left(r_{s}\right)$ menurut Siegel (1992) digunakan rumus berikut:

$$
r s=1-\frac{6 \sum_{i-l}^{n} d i^{2}}{n\left(n^{2}-1\right)}
$$

dimana $r s$ adalah Koefisien korelasi Rank Spearman, $\mathrm{n}$ adalah Jumlah responden, di merupakan selisih antara rangking variabel bebas dengan variabel tak bebas pada responden $\mathrm{ke}-\mathrm{i}$, sementara $\mathrm{i}$ adalah jumlah respoden $(1,2,3, \ldots n)$. Untuk menguji signifikansi dari hubungan tersebut digunakan uji t.

\section{HASIL DAN PEMBAHASAN}

\section{Karakteristik Anggota Koperasi BMT}

Karakteristik yang diteliti pada anggota koperasi Baitul Mal Watamil (BMT) Desa Srikaton Kecamatan Pondok Kelapa Kabupaten Bengkulu Utara dalam penelitian ini meliputi pendidikan formal, jumlah tanggungan keluarga, pengalaman berusaha tani sawit, penerimaan usaha tani, persepsi terhadap program kredit koperasi BMT serta motivasi dalam pengembalian kredit tersebut.

Anggota koperasi BMT yang memiliki tingkat pendidikan formal dengan kategori rendah sebanyak 5,71 \%, kategori tinggi $20 \%$, dan selebihnya $74,28 \%$ dengan kategorisedang.Berdasarkan kondisi di atas dapat diketahui bahwa anggota koperasi BMT tingkat pendidikan formalnya termasuk kategori sedang, artinya tingkat pendidikan formal mereka rata-rata tamat SMP.

Jumlah tanggungan keluarga mengambarkan jumlah orang yang menjadi tanggungan kepala keluarga responden diketahui bahwa rata-rata jumlah tanggungan keluarga anggota koperasi BMT adalah 3,85 jiwa, dengan kisaran 1 sampai dengan 7 . Sebanyak $40 \%$ petani memiliki jumlah tanggungan keluarga 
dengan kategori rendah, 25,71\% petani pada kategori sedang, dan 34,28\% petani yang berada pada kategori yang tinggi.

Pengalaman kerja akan membantu petani khususnya anggota koperasi BMT dalam dalam meningkatkan produksi lahan sawit mereka. Dan disamping itu juga,semakin lama pengalaman berusahataninya diasumsikan akan mempengaruhi pola pikir petani terhadap pentingnya modal dan ini tentunya akan memotivasi para petani yang mana mereka adalah anggota koperasi BMT untuk menjaga kepercayaan koperasi terhadap mereka.sebesar 28,57\%anggota koperasi BMT memiliki pengalaman pada kategori tinggi, sedangkan pengalaman pada kategori sedang dan rendah masing-masing adalah $31,4 \%$ dan $40 \%$. Pengalaman dalam berusahatani sawit tentunya akan sangat membantu tingkat kematangan dan pola pikir petani dalam membuat keputusan. Di mana setiap keputusan yang diambil akan memberi manfaat yang baik bagi diri petani itu sendiri.

Tingkat luas lahan petani merupakan suatu gambaran di mana petani memiliki asset yang dapat dimanfaatkan untuk mendapatkan hasil. Di mana dapat diasumsikan semakin tinggi atau banyak asset ini maka tingkat penerimaan yang didapat akan semakin baik pula. Dengan penerimaan yang tinggi maka didapatkan income bersih yang baik pula, sehingga petani sebagai anggota koperasi dapat menyisihkan sebahagian pendapatannya untuk membayar kredit yang telah mereka pinjam pada koperasi. Data di lapangan menunjukkan bahwa hampir setengah dari anggota koperasi BMT $(45,71 \%)$ memiliki tingkat luas lahan dengan kategori rendah.34,28 \% berada pada kategori sedang dan pada kategori tinggi sebesar $20 \%$. Rata-rata tingat luas lahan yang dimiliki petani anggota koperasi BMT adalah 1,47Ha dengan kisaran 1 - 3 Ha. Kondisi ini menunjukkan bahwa masih rendahnya tingkat kepemilikan lahan petani anggota koperasi BMT.

Motivasi merupakan suatu bentuk reaksi terhadap kebutuhan manusia yang menimbulkan tensi dalam diri manusia yaitu keinginan terhadap sesuatu yang belum terpenuhi dalam hidupnya sehingga mereka terdorong untuk melakukan tindakan guna memenuhi dan memuaskan keinginannya. Sebanyak $20 \%$ anggota memiliki tingkat penerimaan dengan kategori tinggi, 34,28\% anggota dengan kategori sedang dan $45,71 \%$ anggota dengan kategori rendah. Rata-rata tingkat penerimaan anggota koperasi BMT adalah Rp. 17.606.714,29. Dengan kisaran Rp. 8.910.000 sampai dengan Rp. 37.056.250. Rendahnya penerimaan ini diakibatkan iklim kemarau yang berkepanjangan sehingga produtivitas lahan yang petani miliki tidak dapat dimaksimalkan. Berdasarkan fakta yang didapat di lapangan, kebanyakan para petani mengeluhkan hal ini. Hampir 30\% dari produksi yang biasa mereka dapat berkurang akibat musim kemarau.

Jaminan diperlukan untuk menanggung pembayaran kredit macet. Calon debitur umumnya diminta untuk menyediakan jaminan berupa agunan yang berkualitas tinggi yang nilainya minimal sebesar jumlah kredit atau pembiayaan yang diterimanya.dapat kita lihat beberapa kategori besar nilai jaminan yang diberikan oleh pihak petanianggota koperasi yang mana sebagai kreditur. Yakni 
rata-rata besar nilai jaminan yang diberikan adalah $\quad R p$ 11.285.714,29. Dengan kisaran Rp. 0 sampai dengan Rp.100.000.000. Sebanyak 17,14\%petani memberikan jaminan dengan besaran nilai yang termasuk ke dalam kategori tinggi17,14 \% dan selebihnya termasuk ke dalam kategori sedang 82,85\% sedangkan pada kategori rendah tidak ada sama sekali. Lebih dari $60 \%$ total petani anggota koperasi BMT yang mendapatkan pinjaman dari koperasi tidak dikenakan wajib memberikan jaminan atas pinjaman. Hal ini dapat terjadi karena berdasarkan keterangan dari pihak pengurus koperasi, petani tersebut telah dipercaya $100 \%$ oleh pihak koperasi bahwa mereka pasti dapat menyelesaikan kredit mereka. Dan adapun yang menjadi bahan pertimbangan bagi pihak koperasi dalam masalah ini adalah petani tersebut dapat menyelesaikan kredit yang didapat sebelum-sebelumnya

\section{Tingkat Persepsi}

Persepsi diidentifikasikan dari penilaian petani responden tentang peranan koperasi BMT dan keuntungan bagi setiap anggotanya. Apakah keberadaan koperasi ini memberikan dampak positif bagi para petani khususnya anggota koperasi BM tersebut. Sebagian besar tingkat persepsi petani berada pada katagori sedang yaitu 77,14 \% sedangkan sisanya pada kagori tinggi sebanyak $14,28 \%$ dan rendah sebanyak $8,57 \%$ dengan rata-rata skor sebesar 31,77. Dan kisaran skornya adalah 26 sampai dengan 36.

Kondisi tersebut bisa dikatakan bahwa untuk tingkat persepsi petani sebagai anggota koperasi sudah cukup baik. Hal ini tentu akan memberikan dampak positif bagi motivasi petani sebagai anggota koperasi dalam pengembalian kredit.

\section{Tingkat Motivasi untuk Mengembalikan Kredit}

Motivasi merupakan suatu bentuk reaksi terhadap kebutuhan manusia yang menimbulkan tensi dalam diri manusia yaitu keinginan terhadap sesuatu yang belum terpenuhi dalam hidupnya sehingga mereka terdorong untuk melakukan tindakan guna memenuhi dan memuaskan keinginannya. Sebanyak $68,57 \%$ anggota memiliki motivasi dengan kategori tinggi, kemudian 25,71 \% anggota dengan kategori sedang, hanya 5,7\% anggota dengan kategori rendah. Rata-rata skor motivasi kerja anggota koperasi BMT adalah 22,48 dengan kisaran skor 17 sampai dengan 24 .

Banyaknya anggota yang memiliki motivasi yang baik disebabkan adanya keinginan untuk terus menjaga kepercayaan pihak koperasi terhadap mereka. Karena bagi petani dengan adanya koperasi BMT ini mereka merasa sangat terbantu khususnya dalam hal permodalan. 


\section{Tingkat Pengembalian Kredit}

Setiap kredit yang disalurkan kepada petani, maka petani harus mengembalikan kredit tersebut sesuai dengan kesepakatan antara petani sebagai kreditur dengan pihak koperasi beserta bunganya. Bunga kredit yang diperoleh koperasi merupakan pendapatan yang dapat meningkatkan profitabilitas. Profitabilitas sangat penting bagi koperasi karena dari keadaan tingkat profitabilitas maka akan diketahui suatu koperasi itu sehat atau tidak. Dengan demikian adanya tingkat profitabilitas yang tinggi maka kelangsungan usaha koperasi akan terjaga dengan baik. Semakin tinggi tingkat pengembalian kredit yang ada maka dapat dianalogikan bahwa koperasi ini telah berjalan dengan seperti apa yang diharapkan.

Tingkat pengembalian kredit anggota koperasi BMT berada pada katagori tinggi yaitu sebesar 45,71\% pada tingkat sedang hanya 28,571 \% dan rendah sebanyak 25,714 \%. Di mana rata-rata skor yang didapat yakni 86,2 dengan kisaran 50 sampai dengan 100.

Pada penelitian ini apabila dilihat secara keseluruhan tingkat pengembalian kredit anggota koperasi BMT sudah cukup baik karena hampir kurang dari seperempat petani yang menjadi responden penelitian tingkat pengembalian kredit mereka terdapat pada kategori sedang dan tinggi, hal ini berarti bahwa mereka dapat mengembalikan kredit sesuai dengan waktu yang telah disepakati. Walau belum mendekati angka 100 \% untuk ukuran koperasi yang masih baru hal ini sudah bisa dikatakan cukup baik.

\section{Hubungan Karakteristik Anggota koperasi BMT Dengan Tingkat Motivasi Petani Dalam Pengembalian Kredit.}

Untuk melihat hubungan antara pendidikan formal, tanggungan keluarga, lama usaha tani, luas lahan, penerimaan usahatani, nilai jaminan, dan persepsi terhadap tingkat motivasi dalam pengembalian kredit digunakan uji Rank Spearman. Hasil uji statistik yang dilakukan dapat dilihat pada Tabel 1. pada uji statistik ini digunakan faktor koreksi karena terdapat nilai data yang seragam pada penelitian ini.

Hasil analisis menunjukkan bahwa variabel pendidikan tidak berhubungan nyata dengan tingkat motivasianggota koperasi BMT pada taraf kepercayaan $90 \%$ hal ini dapat dilihat pada t-hitung yang lebih kecil dari t-tabel untuk Y $(1,15<1,685)$. Dengan demikian Ho diterima, yang berarti tingkat pendidikan formal tidak berhubungan nyata dengan tingkat motivasi anggota koperasi dalam pengembalian kredit. Tidak berhubungan nyata tingkat pendidikan formal dengan tingkat motivasiini mungkin disebabkan karena untuk memahami arti pentingnya koperasi dan program kredit yang diadakan tidak terlalu sulit. Petani tidak dituntut untuk memiliki pendidikan yang baik atau tinggi dalam hal ini. Pengetahuan dan wawasan mereka berkembang dengan baik seiring dengan pengalaman yang mereka dapati.Pengetahuan dan wawasan pun mereka bisa dapatkan dari seringnya interaksi dan komunikasi 
yang terjadi baik di antara petani dengan pihak koperasi maupun yang terjadi di antara sesama para petani itu sendiri. Hasil penelitian ini sejalan dengan hasil penelitian yang dilakukan oleh Marlena (1999) yang menyatakan bahwa tingkat pendidikan formal petani tidak berhubungan nyata terhadap tingkat pendidikan formal pada taraf kepercayaan 95\%.Lain halnya dengan hasil penelitian yang didapat oleh Hasibuan (2010) di mana tingkat pendidikan berpengaruh nyata terhadap tingkat pengembalian tunggakan Kupedes BRI Unit Cijeruk, Kabupaten Bogor, Jawa Barat.

Tabel 1. Hasil Analisis Korelasi Rank Spearman Variabel Xi dan Variabel Y

\begin{tabular}{cclc}
\hline No & \multicolumn{1}{c}{ Variabel bebas } & Y \\
\hline 1 & X1 & Pendidikan formal & $0,20(1,15)$ \\
2 & X2 & Tanggungan keluarga & $0,06(0,39)$ \\
3 & X3 & Pengalaman berusahatani & $0,39\left(2,26^{*}\right)$ \\
4 & X4 & Luas lahan & $0,11(0,61)$ \\
5 & X5 & Penerimaan & $0,26(1,46)$ \\
6 & X6 & Nilai jaminan (agunan) & $0,32\left(1,83^{*}\right)$ \\
7 & X7 & Persepsi & $0,40\left(2,25^{*}\right)$ \\
\hline
\end{tabular}

Sumber: Data primer diolah, Desember 2011

Keterangan

- $\mathrm{t}(35 ; 0,005)=+/-1,685$ dan * berhubungan nyata dengan tingkat kepercayaan $90 \%$.

- Angka yang bercetak miring merupakan nilai rs dengan menggunakan faktor koreksi.

- Angka dalam kurung merupakan $t$-hitung $\mathbf{X}_{\mathbf{i}}$ terhadap $\mathbf{Y}$.

Hasil analisis menunjukkan bahwa variabel jumlah tanggungan keluarga tidak berhubungan nyata dengan tingkat motivasi anggota koperasi BMT dalam pengembalian kredit pada taraf kepercayaan $90 \%$ hal ini dapat dilihat pada $\mathrm{t}$ hitung yang lebih kecil dari t-tabel untuk $Y(0,39<1,685)$. Dengan demikian Ho diterima dan Hi ditolak, yang berarti tingkat jumlah tanggungan keluarga tidak berhubungan nyata dengan tingkat motivasi anggota koperasi tersebut. Begitu juga halnya dengan penelitian yang dilakukan oleh Hasibuan (2010) di mana jumlah tanggungan keluarga ini berhubungan tidak signifikan terhadap tingkat pengembalian tunggakan di Kupedes BRI. Semakin banyak jumlah tanggungan keluarga responden menyebabkan responden semakin tidak lancar dalam pengembalian tunggakan Kupedes, dan sebaliknya semakin sedikit jumlah tanggungan keluarga maka semakin besar peluang pengembalian tunggakan Kupedes, jelasnya lebih lanjut. Memang pada dasarnya semakin banyak jumlah tanggungan keluarga maka akan semakin kecil pula penghasilan yang dapat disisihkan petani untuk membayar kredit mereka. Tapi bagaimana pula seandainya yang menjadi tanggungan pun memiliki penghasilan juga. Hal ini tentu akan sangat membantu kondisi keuangan rumah tangga petani itu sendiri. 
Kondisi seperti ini dapat jumpai pada beberapa orang petani yang menjadi responden di lapangan. Di samping itu juga pola kehidupan sederhana yang mereka terapkan cukup membantu, sehingga mereka mampu menyimpan uang penghasilan yang mereka dapati untuk membayar kredit pada koperasi.

Hasil analisis menunjukan bahwa variabel pengalaman terhadap variabel tingkat motivasi berhubungan nyata pada taraf kepercayaan $90 \%$ dengan nilai thitung lebih besar dari t-tabel $(2,26>1,685)$ yang berarti Hi ditolak dan Ho diterima. Adanya hubungan nyata antara pengalaman berusaha tani dengan tingkat motivasi karena kegiatan usahatani dilakukan secara turun - temurun sehingga petani sudah mempunyai konsep dan cara sendiri untuk mengelola usahataninya baik pada segi kegiatan produksinya maupun pengaturan finansial yang mereka miliki. Hal ini tidak sejalan dengan apa yang didapati dari penelitian yang dilakukan oleh Hasibuan (2010) di mana variable pengalaman berusaha berhubungan tidak signifikan terhadap tingkat pengembalian tunggakan di Kupedes BRI. Semakin responden berpengalaman di bidang usahanya membuatnya semakin meremehkan kewajibannya terhadap pengembalian kredit karena sebagian pendapatan dari hasil usaha akan terus dipakai untuk pengembangan usahanya, jelasnya. Begitu juga dengan hasil penelitian Triwibowo (2009) di mana ia mendapatkan belum cukup bukti untuk mengatakan bahwa pengalaman usahaber pengaruh nyata terhadap pengembalian kredit oleh nasabah BPR Rama Ganda.

Tingkat luas lahan anggota koperasi BMT berhubungan tidak nyata terhadap tingkat motivasi anggota koperasi BMT dalam pengembalian kredit pada taraf kepercayaan $90 \%$. Ini ditunjukan dari nilai t-hitung yang lebih kecil dari t-tabel pada $Y_{1}$ sebesar $(0,61<1,685)$ yang berarti Ho diterima dan Hi ditolak. Lahan merupakan sumber daya yang sangat pentingdalam berusaha tani. Jumlah produksi yang tinggi akan menghasilkan penerimaan yang tinggi pula. Dengan tingginya penerimaan dengan diimbangi pengeluaran yang sedikit akan memberikan kesempatan kepada para petani anggota koperasi BMT untuk dapat menyisihkan uangnya demi membayar angsuran kredit yang telah mereka pinjam pada koperasi. Akan tetapi kondisi di lapangan sangat berbeda, luas lahan tidak mempunyai hubungan sama sekali terhadap motivasi anggota koperasi untuk membayar kredit. Dengan kata lain, petani yang memiliki luas lahan baik itu besar maupun kecil mereka sama-sama mempunyai peluang yang sama untuk dinilai memiliki motivasi yang baik atau sebaliknya.

Tingkat penerimaan anggota koperasi BMT berhubungan tidak nyata terhadap tingkat motivasi anggota koperasi BMT dalam pengembalian kredit pada taraf kepercayaan $90 \%$. Ini ditunjukan dari nilai t-hitung yang lebih kecil dari t-tabel pada $Y_{1}$ sebesar $(1,46<1,685)$ yang berarti Ho diterima dan Hi ditolak. Hasil penelitian ini sejalan dengan hasil penelitian yang dilakukan oleh Marlena (1999) yang menyatakan bahwa omset atau tingkat penerimaan petani tidak berhubungan nyata dengan pengembalian kredit. Lain halnya dengan hasil penelitian yang didapat oleh Hasibuan (2010) di mana tingkat penerimaan berpengaruh nyata terhadap tingkat pengembalian tunggakan Kupedes BRI Unit Cijeruk, Kabupaten Bogor, Jawa Barat. Tentu saja semakin besar 
penerimaan atau omset usaha responden diharapkan responden semakin lancar dalam pengembalian kredit. Akan tetapi besarnya omzet usaha bukan berarti dapat membayar kredit tepat waktu, karena makin besar omzet usaha dapat dimungkinkan juga makin besar pengeluaran. Akibatnya semakin sedikit penghasilan yang dialokasikan untuk pembayaran kredit.

Besarnya nilai jaminan atau agunan anggota koperasi BMT berhubungan nyata terhadap tingkat motivasi anggota koperasi BMT dalam pengembalian kredit pada taraf kepercayaan $90 \%$. Ini ditunjukan dari nilai t-hitung yang lebih kecil dari t-tabel pada $Y_{1}$ sebesar $(1,83>1,685)$ yang berarti Hi diterima dan Ho ditolak. Hasil penelitian yang didapat oleh Marlena (1999) juga menyatakan demikian, di mana nilai jaminan atau agunan petani berhubungan signifikan dengan pengembalian. Sedangkan hasil penelitian yang dilakukan oleh Hasibuan (2010) menyatakan bahwakredit nilai jaminan atau agunan berhubungan tidak signifikan terhadap tingkat pengembalian tunggakan Kupedes BRI Unit Cijeruk, Kabupaten Bogor, Jawa Barat. Akan tetapi kedua peneliti ini mendapatkan hasil yang sama, di mana nilai jaminan atau agunan mempunyai pengaruh positif terhadap pengembalian kredit atau tunggakan pinjaman.

Tingkat persepsi anggota koperasi BMT berhubungan nyata terhadap tingkat motivasi anggota koperasi BMT dalam pengembalian kredit pada taraf kepercayaan $90 \%$. Ini ditunjukan dari nilai t-hitung yang lebih kecil dari t-tabel pada $Y_{1}$ sebesar $(2,25>1,685)$ yang berarti Hi diterima dan Ho ditolak. Anggota koperasi BMT memiliki pandangan yang cukup baik terhadap koperasi BMT dan program kredit yang dijalankan. Mereka sadar sepenuhnya dengan adanya koperasi ini dan program kredit yang diadakan, para petani (anggota koperasi) merasa sangat terbantu dari permasalahan modal yang biasa mereka hadapi. Walau di lain pihak ada juga beberapa petani yang menjadi responden mengeluhkan tingginya bunga yang dibebankan oleh mereka. Akan tetapi hal ini bukanlah suatu masalah besar bagi mereka. Dengan kesadaran dalam diri yang cukup baik dan penuh rasa tanggung jawab para petani anggota tetap untuk segera menyelesaikan kredit mereka dan membayar angsuran kredit tersebut tepat waktu.

\section{Hubungan Tingkat Motivasi (Y) Dengan Tingkat Pengembalian Kredit Petani Dalam Pengembalian Kredit (Z).}

Untuk melihat hubungan antara tingkat motivasi dalam pengembalian kredit terhadap tingkat pengembalian kredit itu sendiri digunakan uji Rank Spearman. Hasil uji statistik yang dilakukan menunjukan bahwa variabel tingkat motivasi terhadap variabel tingkat pengembalian kredit berhubungan nyata pada taraf kepercayaan 90\% dengan nilai t-hitung lebih besar dari t-tabel $(2,51>1,685)$ yang berarti Hi ditolak dan Ho diterima. Kondisi ini menjelaskan bahwa motivasi yang baik pada petani yang menjadi anggota koperasi tentu akan memberikan dampak positif bagi koperasi BMT itu sendiri. Hal tersebut 
dikarenakan tingkat pengembalian kredit yang ada dalam keadaan cukup baik pula. Hasil penelitian ini tidak sama dengan apa yang ditemukan oleh Amarta (2008) di mana tingkat motivasi tidak berhubungan signifikan dengan pengembalian beban bunga kredit. Hal ini dikemukakan dengan alasan kurang tersedianya alokasi waktu sehingga petani tidak mampu meningkatkan penerimaan mereka.

\section{SIMPULAN DAN SARAN}

\section{Simpulan}

Kesimpulan dari hasil penelitian ini adalah :

1) Motivasi petani yang menjadi anggota koperasi pada koperasiBaitul Maal Wat Tamil (BMT) di Desa SrikatonKecamatan Pondok Kelapa Kabupaten Bengkulu Tengah dalam pengembalian kredit dapat dikategorikan sedang atau dirasakan sudah cukup baik.

2) Karakteristik anggota koperasi BMT yang berhubungan nyata dengan tingkat motivasipetani dalam pengembalian kredit adalah tingkat pengalaman dalam usahatani sawit (X3),nilai agunan (X6) dan tingkat persepsi petani terhadap koperasi BMT terhadap program kredit koperasi itu sendiri (X7), sedangkan faktor lainnya seperti pendidikan formal (X1), jumlah tanggungan keluarga (X2), luas lahan (X4) dan penerimaan (X5) tidak berhubungan nyata dengan tingkat motivasi petani dalam pengembalian kredit.

3) Variabel tingkat motivasi dalam pengembalian kredit pada petani yang menjadi anggota koperasi BMT berhubungan nyata dengan tingkat pengembalian kredit itu sendiri.

\section{Saran}

Kebutuhan informasi petani perlu diimbangi dengan ketersediaan sumber-sumber informasi. Sehingga perlu dipertimbangakan beberapa hal sebagai berikut :

1. Pelaksanaan pinjaman kredit bagi petani tanaman sawit diperlukan tindakan lanjutan berupa pendampingan dalam penggunaan kredit maupun pembinaan usaha yangdijalankan petani.Ini diharapkan dapat meningkatkan motivasi yang ada pada petani yang menjadi anggota koperasi BMT, sehingga tingkat pengembalian kredit (repayment capacity) usahanya meningkat sesuai harapan.

2. Koperasi Baitul Maal Wat Tamiil hendaknya menerapkan model pelayanan pembiayaan yangideal untuk petani yang ada diwilayah kerjanya yaitu dengan menghindaripersyaratan agunan sertifikat tanah, kreditdalam bentuk uang tunai,dan pengajuan/penyaluran kredit melalui kelompok tani serta menurunkan tingkat suku bunga kredit. Hal 
ini perlu dilakukan mengingat petani merupakan objek yang memang perlu dibantu dan bantuan yang diberikan tersebut dapat dimanfaatkan oleh mereka secara tepat guna.

\section{DAFTAR PUSTAKA}

Amarta, Dina. 2006. Persepsi Terhadap Pelaksanaan Kredit Sapi dan Faktor-Faktor Yang Berhubungan Dengan Pengembalian Beban Bunga Oleh Buruh Panen Peserta Sistem Integrasi Sawit Sapi (SISS) di PT. AGRICINAL Kabupaten Bengkulu Utara.Jurusan Sosial Ekonomi Fakultas Pertanian Universitas Bengkulu (Tidak Dipublikasikan).

Pertanian (JPP) Vol IX. Lampung.

Marlena, 1999.Kontribusi Pendapatan dan Faktor-Faktor Yang Berhubungan Dengan Motivasi Kerja Petani Sebagai Karyawan Pada Industri Penggilingan Bubuk Kopi.Jurusan Sosial Ekonomi Fakultas Pertanian Universitas Bengkulu (Tidak Dipublikasikan).

Pasaribu, J. 2006. Analisis Tingkat Pengembalian Kredit Nasbah UPKD dan FaktorFaktor Yang Mempengaruhi Pasca Proyek BRDP (Studi Kasus UPKD Sidodadi Kecamatan Pondok Kelapa Kabupaten Bengkulu Utara). Jurusan Sosial Ekonomi Fakultas Pertanian Universitas Bengkulu (Tidak Dipublikasikan).

Siegel, S. 1992. Sistem Nonparametrik. P. T Gramedia Pustaka Utama. Jakarta.

Sugiyono. 1997. Statistik Untuk Penelitian..Alfabeta. Bandung.

Triwibowo, D . 2009. Analisis Faktor-Faktor yang Mempengaruhi Pengambilan Kredit Bermasalah Oleh Nasabah di Sektor Perdagangan Agribisnis, Kasus Pada BPR Rama Ganda [Skripsi]. Program Ekstensi Manajemen Agribisnis. Fakultas Pertanian. Institut Pertanian Bogor. 